\title{
Macroinvertebrate communities associated with macrophyte habitats in a tropical man-made lake (Lake Taabo, Côte d'Ivoire)
}

\author{
M.K. Kouamé(1), M.Y. Dietoa ${ }^{(1)}$, E.O. Edia ${ }^{(1)}$, S.K. Da Costa(2), A. Ouattara ${ }^{(1)}$, \\ G. Gourène ${ }^{(1)}$
}

Received September 21, 2010 / Reçu le 21 septembre 2010

Revised November 24, 2010 / Révisé le 24 novembre 2010

Accepted November 29, 2010 / Accepté le 29 novembre 2010

Key-words: macroinvertebrates, communities, macrophyte habitats, tropical lake

\section{ABSTRACT}

An ecological study was done on Lake Taabo with the main objective of characterising macroinvertebrate communities associated with the microhabitats created mainly by Eichhornia crassipes and other littoral native macrophytes. We sampled organisms in patches of those aquatic macrophytes. Also, some abiotic variables (temperature, transparency, turbidity, $\mathrm{pH}$, TDS, conductivity, dissolved oxygen, $\mathrm{NH}_{4}^{+}, \mathrm{NO}_{3}^{-}, \mathrm{NO}_{2}^{-}, \mathrm{PO}_{4}^{3-}$ and $\mathrm{SiO}_{2}^{-}$) were measured. Overall, forty-three taxa of macroinvertebrates were identified. Ten of them were exclusively associated with water hyacinth while five were only associated with littoral macrophytes. Macroinvertebrate taxa with some of the highest family richness were Gastropoda, Coleoptera, Heteroptera, Odonata and Diptera. The taxon with highest density in both microhabitats was Chironomidae. Although higher values of taxonomic richness $(R s)$, the Shannon index $\left(H^{\prime}\right)$ and evenness $(J)$ were obtained with the water hyacinth habitat, significant differences between the two microhabitats were not observed. Canonical Correspondence Analysis revealed that samples of $E$. crassipes collected in the dry season were characterised by Gastropoda and Odonata, as well as higher values of transparency and ammonia-nitrogen. Baetidae, Hydrophilidae, Chironomidae, Ceratopogonidae, Coenagrionidae, Naucoridae and Ostracoda were most abundant in both $E$. crassipes and littoral macrophyte habitats during the rainy season. This season was characterised by higher levels of nitrates and conductivity.

\section{RÉSUMÉ}

Communautés de macroinvertébrés associés aux macrophytes dans un lac de barrage en milieu tropical (Lac de Taabo, Côte d'Ivoire)

Mots-clés : Une étude écologique a été effectuée dans le lac Taabo, avec pour objectif prinmacroinvertébrés, cipal de caractériser les communautés de macroinvertébrés associés aux microcommunautés, habitats créés principalement par Eichhornia crassipes et les végétaux indigènes. macrophytes, lac tropical Les organismes ont été échantillonnés dans les plants de ces végétaux, natif et indigène. Aussi, quelques variables abiotiques (température, transparence, turbidité, $\mathrm{pH}$, TDS, conductivité, oxygène dissous, $\mathrm{NH}_{4}^{+}, \mathrm{NO}_{3}^{-}, \mathrm{NO}_{2}^{-}, \mathrm{PO}_{4}^{3-}$ et $\mathrm{SiO}_{2}^{-}$) ont-elles

(1) Laboratoire d'Environnement et de Biologie Aquatique (LEBA), UFR - Sciences et Gestion de l'Environnement, Université d'Abobo-Adjamé, Abidjan, Côte d'Ivoire, martin_kouame@yahoo.fr

(2) Centre National de Recherche Agronomique (CNRA), Programme Pêche et Aquaculture Continentale, Abidjan, Côte d'Ivoire 
été mesurées. Au total, quarante-trois taxa de macroinvertébrés ont été identifiés. Dix d'entre eux étaient exclusivement associés à la jacinthe d'eau tandis que cinq étaient seulement associés à la végétation indigène. Les taxa de macroinvertébrés ayant les richesses les plus élevées en terme de famille sont les gastéropodes, coléoptères, hétéroptères, odonates et diptères. Le taxon avec la densité la plus élevée dans les deux microhabitats était la famille des Chironomidae. Bien que les valeurs les plus grandes de richesse taxonomique $(R s)$, d'indice de Shannon $\left(H^{\prime}\right)$ et d'équitabilité (J) soient obtenues au sein de la jacinthe d'eau, aucune différence significative entre les deux microhabitats n'a été observée. L'analyse canonique des correspondances a révélé que les échantillons de $E$. crassipes collectés en saison sèche étaient caractérisés par les gastéropodes et les odonates, aussi bien que les valeurs les plus élevées de transparence et d'ammonium. Les Baetidae, Hydrophilidae, Chironomidae, Ceratopogonidae, Coenagrionidae, Naucoridae et Ostracodes sont les plus abondants dans les deux habitats pendant la saison pluvieuse. Cette saison est caractérisée par des valeurs élevées des nitrates et de la conductivité.

\section{INTRODUCTION}

Submerged and floating macrophyte communities serve a number of important functions. They play a crucial role for animals and lower plants in aquatic ecosystems by providing habitat complexity and breeding areas, as well as being substrata for periphyton and sites of abundant food production for many aquatic animals (Lodge, 1991; Diehl, 1992; Zimmer et al., 2000; Rennie and Jackson, 2005). In wetlands, a well-developed macrophyte community provides shelter against predation for vulnerable prey species such as zooplankton and small fish (Crowder and Cooper, 1982; Diehl, 1992; Batzer, 1998). In addition, macrophytes are usually covered by epiphytes that are grazed upon by several invertebrates (van den Berg et al., 1997) that are themselves an important component of the diet of many fish and birds (Batzer and Wissinger, 1996). Therefore, macrophytes influence the diversity, abundance and distribution pattern of aquatic invertebrates and vertebrates (Williams, 1980; Wilzbach, 1985; Wilzbach et al., 1986). In general, lakes with a well-developed macrophyte community are characterised by a more diverse community of zooplankton (Timms and Moss, 1984), benthos (Munro, 1966) and fish (Olson et al., 1994). Within a single lake the vegetation sites often support a greater diversity of macroinvertebrates than the open water sites (Olson et al., 1994; Savage and Beaumont, 1997). Some species of the major secondary producers (rotifers, cladocerans and insect larvae) are commonly found in both pelagic and vegetation areas, whereas others are found in, or in the vicinity of vegetation stands (Campbell et al., 1982; Havens, 1991; Lauridsen and Buenk, 1996; Vijverberg and Boersma, 1997).

However, non-native species such as the water hyacinth Eichhornia crassipes (Martius) Solms-Laubach (Pontederiales: Pontederiaceae) may seriously alter the functions that macrophytes provide (Luken and Thieret, 1997). Since its introduction in Egypt (1879-1892), water hyacinth has spread throughout Africa's lakes and impoundments. Its prolific growth causes considerable economic problems and affects fisheries, traffic, irrigation, water supply and the whole ecology of the infested lake (Ogutu-Ohwayo et al., 1997). It tends to invade water bodies where hydrological or nutrient conditions have been altered by human activities (Barret, 1989).

Surprisingly few studies have reported the influence of macrophytes on diversity of invertebrates in freshwater ecosystems (e.g., Brendonck et al., 2003; Toft et al., 2003; Albertoni et al., 2007; Thomaz et al., 2008; Kovalenko et al., 2010). In addition to the prevailing environmental conditions, there are many other factors that may affect epiphytic and plant-associated invertebrate distribution. These are invertebrate predominant life form, mobility, predation and seasonality (Downing and Cyr, 1985; Cheruvelil et al., 2001; Taniguchi et al., 2003). Therefore, it is important to measure invertebrates on macrophytes and separately on water hyacinth to gain a better understanding of the impact of $E$. crassipes on diversity of invertebrates. 
Macroinvertebrates in man-made lakes are little studied in Côte d'Ivoire. To our knowledge, only Kouamé et al. (2010) has conducted a study relative to aquatic macroinvertebrates associated with water hyacinth in Lake Taabo. Nevertheless, Kouassi (2007) has reported that this floating invader plant has considerably colonised $26 \%$ of this lake's surface.

This study aims to fill part of an important gap in biodiversity knowledge by reporting the interacting ecological roles of macrophytes and invertebrates in the aquatic ecosystem Lake Taabo. Also, the study aims to compare invertebrates associated with water hyacinth with those associated with other macrophyte communities in the littoral zone of Lake Taabo for better understanding of the influences of the water hyacinth on diversity of invertebrates. In addition, the effects of various water properties on abundance and distribution of the invertebrates were investigated.

\section{MATERIAL AND METHODS}

\section{> STUDY AREA}

Lake Taabo is a reservoir located between $6^{\circ} 19^{\prime}-6^{\circ} 40^{\prime} \mathrm{N}$ latitude and $5^{\circ} 07^{\prime}-5^{\circ} 26^{\prime} \mathrm{W}$ longitude on the Bandama River, approximately $110 \mathrm{~km}$ downstream of the confluence of the Bandama and Marahoue rivers. The lake covers a surface area of $69 \mathrm{~km}^{2}$. The climate is tropical and humid with a mean annual temperature of $28.2{ }^{\circ} \mathrm{C}$ (Sakho, 1991). Four seasons occur in the Lake Taabo region: (1) a major dry season (December-March), (2) a major rainy season (AprilJuly), (3) a minor dry season (July-September) and (4) a minor rainy season (SeptemberNovember).

\section{> FIELD SAMPLING}

Sampling in Lake Taabo was done in one year (July 2006-June 2007) wherein seasonal samples of water and samples of macrophytes with their associated macroinvertebrates were collected at five sites located in four different zones; a fluvial zone (Sahoua), a transitional zone (Ahondo), bays (Taabo cité and Courandjourou) and near the dyke (Taabo village) (Figure 1). In this study period, three campaigns were conducted during the dry and wet seasons. Thus, at each site, two surveys were conducted during the dry season (in December 2006, beginning of the dry season (BDS) and in March 2007, end of the dry season (EDS)). Another survey took place at each station in the major rainy season (MRS) (June 2007) during the sampling period.

To sample the macroinvertebrate assemblages associated with each plant community, a $40 \mathrm{~cm} \times 40 \mathrm{~cm}$ "kick-net" with a 500- $\mu \mathrm{m}$ mesh size was used. At each sampling station, macroinvertebrates were collected by submerging the sampling net and sweeping a demarcated quadrat; this quadrat was set up using the surface area of the net (catching area: $0.16 \mathrm{~m}^{2}$ ). Then, the "kick-net" was carefully lifted out of the water to prevent the escape of agile animals. This operation was repeated three times in order to obtain three different subsamples. These subsamples were pooled to constitute the sample of each station per campaign. Subsequently, the sample was preserved in a $10 \%$ formaldehyde solution in a plastic container for further analysis. Some samples of plants were collected for their identification by a specialist at the laboratory.

Simultaneously with the biological sampling, the following water physical and chemical characteristics were recorded in situ between 8 and 10 a.m. at each sampling site in the water column: temperature $\left({ }^{\circ} \mathrm{C}\right)$, transparency $(\mathrm{m})$, turbidity (NTU), hydrogen-ion concentration $(\mathrm{pH})$ ( $\mathrm{pH}$ unit), total dissolved solids (TDS) $\left(\mathrm{mg} \cdot \mathrm{L}^{-1}\right)$, electric conductivity $\left(\mu \mathrm{S} \cdot \mathrm{cm}^{-1}\right)$ and dissolved oxygen $\left(\mathrm{mg} \cdot \mathrm{L}^{-1}\right)$. These measurements of water quality were made using WTW portable battery measuring devices in the field, except transparency which was measured using a Secchi disc. Then, water samples from each station were taken, stored in polyethylene bottles $(500 \mathrm{~mL})$ and kept at a temperature below $4{ }^{\circ} \mathrm{C}$ to stop all the activities and metabolism of the organisms in the water. 


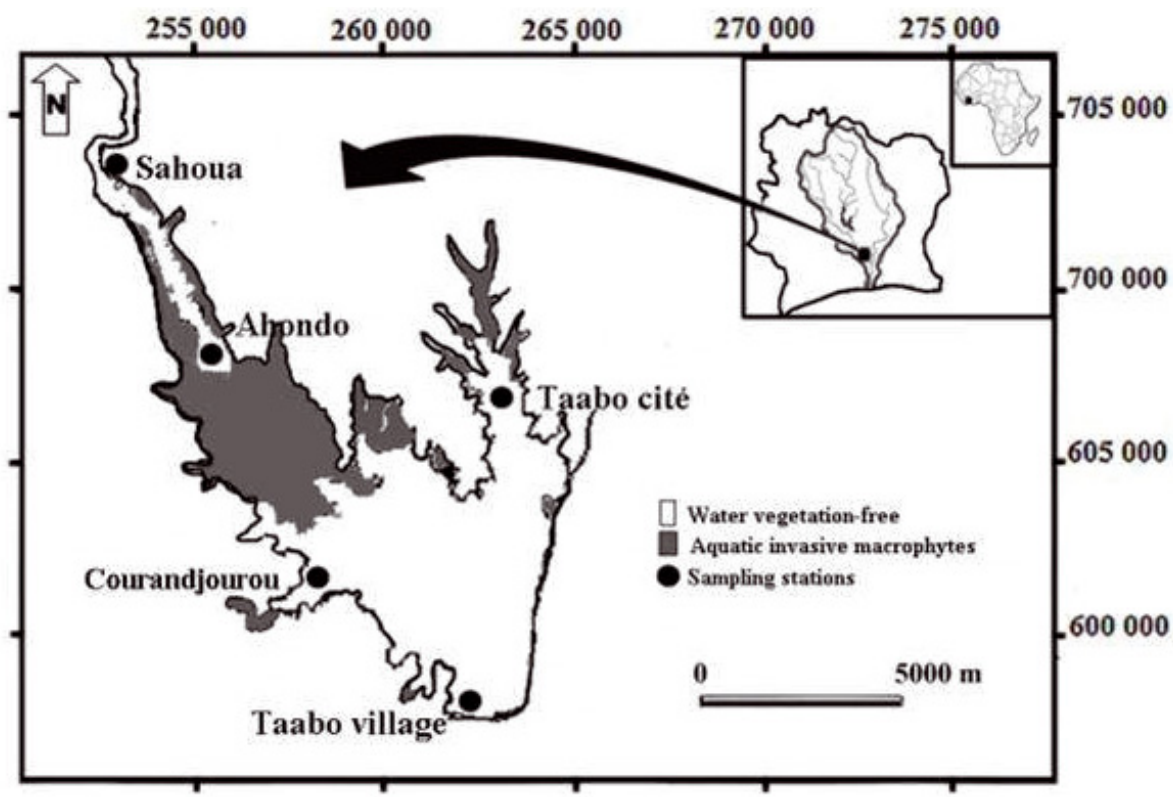

Figure 1

Map of the man-made Lake Taabo, showing sampling stations (Kouassi, 2007).

Figure 1

Carte du lac de barrage de Taabo, montrant les stations d'échantillonnage (Kouassi, 2007).

In the laboratory, all macroinvertebrates were separated from the collected plants by washing each plant sample to concentrate the organisms in a tank and then plants were weighed to estimate plant wet biomass. Also, samples of macrophytes were identified by a specialist. The solution collected in the tank was then sieved at $500 \mu \mathrm{m}$ to collect only the macroinvertebrates, which were fixed in $5 \%$ buffered formaldehyde solution. Large macroinvertebrates were sorted by the naked eye while smaller fauna was sorted under a dissecting microscope. All the sorted samples of invertebrates were separated, counted and identified to the lowest practical taxonomic level with light microscopy according to keys proposed by Durand and Lévêque (1980, 1981), Déjoux et al. (1981), Diomandé et al. (2000) and de Moor et al. (2003). In most cases, taxonomic classification was done at family level, although Kouamé et al. (2010) presented the list of species recorded from water hyacinth. Indeed, only a few taxa from littoral macrophytes were identified at genus or species level. However, in some groups, it was not possible to go further than phylum level. Therefore, the family level was retained for analyses.

Brought back to the laboratory, the water samples were kept in a refrigerator for further determination of ammonium-nitrogen $\left(\mathrm{NH}_{4}^{+}\right)\left(\mathrm{mg} \cdot \mathrm{L}^{-1}\right)$, nitrate $\left(\mathrm{NO}_{3}^{-}\right)\left(\mathrm{mg} \cdot \mathrm{L}^{-1}\right)$, nitrite $\left(\mathrm{NO}_{2}^{-}\right)\left(\mu \mathrm{mol} \cdot \mathrm{L}^{-1}\right)$, phosphate $\left(\mathrm{PO}_{4}^{3-}\right)\left(\mu \mathrm{mol} \cdot \mathrm{L}^{-1}\right)$ and silica $\left(\mathrm{SiO}_{2}^{-}\right)\left(\mathrm{mg} \cdot \mathrm{L}^{-1}\right)$. The samples were filtered through Whatman GF/C fibreglass filters. Afterwards, in accordance with the standard method procedures (American Public Health Association, 1989), the concentrations of these parameters were determined by using a spectrophotometer, model HACH DR 2010, at a specified wavelength.

\section{> DATA INTERPRETATION AND STATISTICAL TESTS}

The macroinvertebrate composition and structure were evaluated by taxonomic richness (number of taxa), diversity (Shannon-Wiener index), evenness (Pielou index) (Magurran, 1988) and abundance. However, all analyses were done on standardised data. To obtain such data, all data were compiled and converted to density using the formula: density $=N * 10000 / A$, 
where $N$ is the number of individuals in the sample and $A$ is the catching surface area $\left(\mathrm{cm}^{2}\right)$. Then, the abundance of macroinvertebrates was calculated as the number of individuals per square metre (ind $\cdot \mathrm{m}^{-2}$ ) according to the catching surface area. The frequency of occurrence was classified as the number sampled as: sporadic ( $<10 \%)$, low frequency $(10-40 \%)$, frequent $(40-70 \%)$ or very frequent $(>70 \%)$. Using a matrix of total taxa abundance per habitat, the taxonomic similarity between macrophyte habitats was investigated with hierarchical analysis (Ward linkage method). All indices as well as individual species densities were tested by the Kruskal-Wallis test and the Mann-Whitney $U$ test for significant differences among the considered habitat types and also among the considered seasons. The macroinvertebrate community structure was analysed using length-frequency distributions, which were tested by the Shapiro-Wilk test.

For the multivariate analysis, the data were drawn up in the form of two matrices: one matrix of macroinvertebrate taxa counts per habitat type and another matrix of water properties. Constrained ordination canonical correspondence analysis (CCA) was carried out on these two matrices in order to search for and define the best explanatory water properties characterising the macrophyte habitats and influencing the distribution of the associated macroinvertebrates. The statistical significance of the first four ordination axes was tested by using a Monte Carlo permutation test with 499 permutations under a reduced model. This analysis was performed using the software CANOCO version 4.5 (ter Braak and Smilauer, 2002). Before performing this CCA, all sporadic macroinvertebrates were removed from the database. Also, only independent water parameters were considered for the CCA analysis after computing correlation coefficients between those variables.

\section{RESULTS}

\section{> PHYSICO-CHEMICAL PROPERTIES OF THE LAKE}

The water parameters recorded, considering the whole lake, are summarised in Table I. Significant variation in the water parameters was not observed at the $5 \%$ level among the sampling zones (ANOVA results of Kruskal-Wallis test, $P>0.05$ ), except for turbidity. This parameter varied significantly among the zones considered $\left(H_{3,22}=10.12 ; P=0.017\right)$. This significant variation in turbidity was observed between the fluvial zone and the site near the dyke $(P=0.026)$. Higher values were registered in the fluvial zone while lower values were observed near the dyke. This difference was outlined by a multiple comparison test performed after the Kruskal-Wallis test. However, concerning the other environmental variables recorded, high values were observed in bay zones, except ammonia-nitrogen, for which high levels were recorded in the zone near the dyke.

The seasonal variations in the independent environmental variables of the lake outlined by the Kruskal-Wallis test are illustrated in Figure 2. Only pH $(P=0.256)$ and turbidity $(P=0.461)$ were not significantly different from one season to another. However, high levels of $\mathrm{pH}$ were registered at the beginning of the dry season (BDS). Higher levels of turbidity were observed in the rainy season (MRS), while lower levels were recorded at the end of the dry season (EDS). Further to the Kruskal-Wallis test, a multiple comparison test showed that all the other variables, except dissolved oxygen, varied significantly between the MRS and BDS $(P<0.05)$. Higher values of temperature, conductivity, phosphates and nitrate were recorded in the MRS, while lower values were observed in the BDS (Figure 2). High values of transparency and ammonia-nitrogen were registered in the BDS, while low values were observed in the MRS. Significant variations in temperature and nitrate values were also observed between the BDS and EDS. Higher levels of the two parameters were observed in the EDS, while lower levels were recorded in the BDS (Figure 5). Conductivity and phosphate varied significantly between the MRS and EDS, with high values registered in the MRS. Concerning oxygen values, a significant difference was observed between the MRS and EDS. Higher values were recorded in the MRS, while lower values were observed in the EDS (Figure 2). 
Table I

Abiotic results of the water column from Lake Taabo from July 2006 to June 2007.

Tableau I

Résultats des paramètres abiotiques de la colonne d'eau dans le lac de Taabo de juillet 2006 à juin 2007.

\begin{tabular}{|c|c|c|c|}
\hline & Median & Minimum & Maximum \\
\hline Temperature $\left({ }^{\circ} \mathrm{C}\right)$ & 28.81 & 27.34 & 30.33 \\
\hline Dissolved oxygen $\left(\mathrm{mg} \cdot \mathrm{L}^{-1}\right)$ & 5.29 & 3.62 & 9.20 \\
\hline Dissolved oxygen (\%) & 68.39 & 45.40 & 119.73 \\
\hline Conductivity $\left(\mu \mathrm{S} \cdot \mathrm{cm}^{-1}\right)$ & 76.71 & 66.12 & 122.40 \\
\hline Total dissolved solids $\left(\mathrm{mg} \cdot \mathrm{L}^{-1}\right)$ & 53.35 & 46.60 & 77.90 \\
\hline$\overline{\mathrm{pH}}$ & 7.21 & 6.67 & 7.70 \\
\hline Turbidity (NTU) & 14.69 & 10.86 & 29.60 \\
\hline Transparency (m) & 0.91 & 0.58 & 1.92 \\
\hline Ammonium-nitrogen $\left(\mathrm{mg} \cdot \mathrm{L}^{-1}\right)$ & 0.33 & 0.02 & 1.41 \\
\hline Phosphate $\left(\mu \mathrm{mol} \cdot \mathrm{L}^{-1}\right)$ & 6.10 & 0.24 & 28.47 \\
\hline Nitrite $\left(\mu \mathrm{mol} \cdot \mathrm{L}^{-1}\right)$ & 0.76 & 0.13 & 1.64 \\
\hline Silica $\left(\mathrm{mg} \cdot \mathrm{L}^{-1}\right)$ & 30.12 & 4.35 & 49.95 \\
\hline Nitrate $\left(\mathbf{m g} \cdot \mathrm{L}^{-1}\right)$ & 0.91 & 0.05 & 1.95 \\
\hline
\end{tabular}

\section{> MACROPHYTE DIVERSITY}

Eight aquatic macrophytes were recorded during this study. Eichhornia crassipes, an invasive and floating plant in the lake, was the most frequent and the most abundant species ( $75 \%$ of the total wet biomass of macrophytes). Indeed, it was the only species collected at all the sites during each campaign. The seven other plants, sampled in the littoral vegetation zone of the lake, were composed of Ceratophyllum demersum Linnaeus (Ceratophyllales: Ceratophyllaceae), Commelina diffusa Burm. F. (Commelinales: Commelinaceae), Echinochloa pyramidalis (Lam.) Hitchc. and Chase (Poales: Poaceae), Ipomoea aquatica Forssk. (Solanales: Convolvulaceae), Ludwigia stolonifera Guill. and Perr. Raven (Myrtales: Onagraceae), Polygonum senegalense Meisn. (Polygonales: Polygonaceae) and Rhynchospora corymbosa (Linnaeus) Britton (Cyperales: Cyperaceae). All of them, except I. aquatica, were found at "Taabo cité", a bay zone of this lake. But, among those plants collected at this bay zone, $C$. demersum and L. stolonifera were also found, respectively, at "Courandjourou" (another bay zone) and "Taabo village" (a station located near the dyke of the dam). As for I. aquatica, it was recorded at two sites: "Sahoua" (the fluvial zone) and "Ahondo" (the transitional zone).

\section{>ASSOCIATED MACROINVERTEBRATE COMMUNITIES}

Altogether, 43 taxa of aquatic phytophilous macroinvertebrates were identified from the hyacinth mats and the littoral macrophytes (Table II). This table shows the frequency of occurrence and the density of these taxa recorded from each habitat and the frequency of occurrence of taxa common in both habitats. In total, 28 taxa were found in both habitats of macrophytes. Ten taxa were exclusively epiphytic associated with water hyacinth, while only five taxa were closely associated with littoral macrophyte communities. All these taxa belonged to 12 major groups: Bivalvia, Cladocera, Coleoptera, Diptera, Ephemeroptera, Gastropoda, Heteroptera, Hymenoptera, Odonata, Oligochaeta, Ostracoda and Trichoptera. Of all the total assemblage of macroinvertebrates recorded, the groups with the highest family richness were Gastropoda (8), Coleoptera (7), Heteroptera (6), Odonata (6) and Diptera (5).

In the two microhabitats studied in the lake, the associated macroinvertebrate communities were diverse and most of the taxa were considered sporadic or of low frequency for the whole study period (Table II). Nevertheless, there were differences between the two habitats. 


\section{Table II}

List of phytophilous macroinvertebrate taxa recorded with occurrence and density (ind $\cdot \mathrm{m}^{-2}$ ) for each microhabitat; $E C=$ Eichhornia crassipes, $L M=$ littoral macrophytes; $x=$ sporadic, $x x=$ low frequency, $x x x=$ frequent, $x x x x=$ very frequent.

\section{Tableau II}

Liste des taxons de macroinvertébrés phytophiles enregistrés avec la fréquence d'occurrence et la densité (ind $\cdot \mathrm{m}^{-2}$ ) pour chaque microhabitat; Ec = Eichhornia crassipes, Lm = végétation du littoral; $\mathrm{x}=$ sporadique, $x x=$ peu fréquent, $x x x=$ fréquent, $x x x x=$ très fréquent.

\begin{tabular}{|c|c|c|c|c|c|c|c|}
\hline \multicolumn{3}{|c|}{ Taxa } & \multicolumn{3}{|c|}{ Occurrence } & \multicolumn{2}{|c|}{ Density } \\
\hline Major groups & Family & Acronym & EC & LM & $E C+L M$ & EC & LM \\
\hline Bivalvia & & Biva & $x \mathrm{XX}$ & & & 38 & 0 \\
\hline Cladocera & & Clad & $x$ & & & 106 & 0 \\
\hline \multirow{7}{*}{ Coleoptera } & Curculionidae & Curc & & & 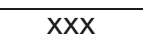 & 138 & 75 \\
\hline & Dryopidae & Dryo & & & $\mathrm{x}$ & 44 & 6 \\
\hline & Dytiscidae & Dyti & & & $x \mathrm{XXX}$ & 519 & 244 \\
\hline & Elmidae & Elmi & & & $x X$ & 106 & 325 \\
\hline & Hygrobiidae & Hygr & $x$ & & & 6 & 0 \\
\hline & Hydrophilidae & Hydr & & & $x x x$ & 356 & 319 \\
\hline & Limnebiidae & Limn & $x$ & & & 6 & 0 \\
\hline \multirow{5}{*}{ Diptera } & Athericidae & Athe & & & $x$ & 6 & 38 \\
\hline & Ceratopogonidae & Cera & & & $x X X$ & 1669 & 213 \\
\hline & Chironomidae & Chir & & & $x x x x$ & 6631 & 7850 \\
\hline & Psychodidae & Psyc & $\mathrm{x}$ & & & 6 & 0 \\
\hline & Stratiomyidae & Stra & & & $x$ & 6 & 6 \\
\hline \multirow{3}{*}{ Ephemeroptera } & Baetidae & Baet & & & $x x x$ & 1000 & 294 \\
\hline & Potamanthidae & Pota & & & $x x$ & 25 & 25 \\
\hline & Leptophlebiidae & Lept & & & $\overline{x X}$ & 125 & 81 \\
\hline \multirow{8}{*}{ Gastropoda } & Ampullaridae & Ampu & & $x$ & & 0 & 6 \\
\hline & Physidae & Phys & & & $x$ & 6 & 19 \\
\hline & Pilidae & Pili & & & $x$ & 6 & 6 \\
\hline & Planorbidae & Plan & & & $x x$ & 94 & 50 \\
\hline & Thiaridae & Thia & & & $\mathrm{XXX}$ & 1025 & 838 \\
\hline & Valvatidae & Valv & $x$ & & & 13 & 0 \\
\hline & Viviparidae & Vivi & $x$ & & & 56 & 0 \\
\hline & Lymnaeidae & Lymn & & & $x x$ & 13 & 6 \\
\hline \multirow{6}{*}{ Heteroptera } & Belostomatidae & Belo & & & $x x$ & 138 & 75 \\
\hline & Gerridae & Gerr & & $x$ & & 0 & 6 \\
\hline & Naucoridae & Nauc & & & $x x$ & 44 & 13 \\
\hline & Nepidae & Nepi & & $x$ & & 0 & 6 \\
\hline & Pleidae & Plei & & & $X X$ & 31 & 88 \\
\hline & Veliidae & Veli & & & $x x$ & 50 & 1019 \\
\hline Hymenoptera & Formicidae & Form & & $\mathrm{XX}$ & & 0 & 31 \\
\hline \multirow{6}{*}{ Odonata } & Aeshnidae & Aesh & & & $x X$ & 38 & 179 \\
\hline & Coenagrionidae & Coen & & & $x x x$ & 225 & 281 \\
\hline & Corduliidae & Cord & $x$ & & & 13 & 0 \\
\hline & Gomphidae & Gomp & & & $x x$ & 181 & 6 \\
\hline & Libellulidae & Libe & & & $X X$ & 431 & 75 \\
\hline & Macromiidae & Macr & & & $x x$ & 6 & 19 \\
\hline Oligochaeta & & Olig & & & $\mathrm{XXX}$ & 519 & 31 \\
\hline Ostracoda & & Ostr & & & $x X$ & 306 & 6 \\
\hline \multirow{3}{*}{ Trichoptera } & Hydropsychidae & Hydro & $x$ & & & 6 & 0 \\
\hline & Hydroptilidae & Hydrop & & $x$ & & 0 & 13 \\
\hline & Philopotamidae & Phil & $x$ & & & 19 & 0 \\
\hline \multicolumn{3}{|l|}{ Taxon richness } & 10 & 5 & 28 & & \\
\hline \multicolumn{3}{|l|}{ Average density } & & & & 326 & 285 \\
\hline
\end{tabular}



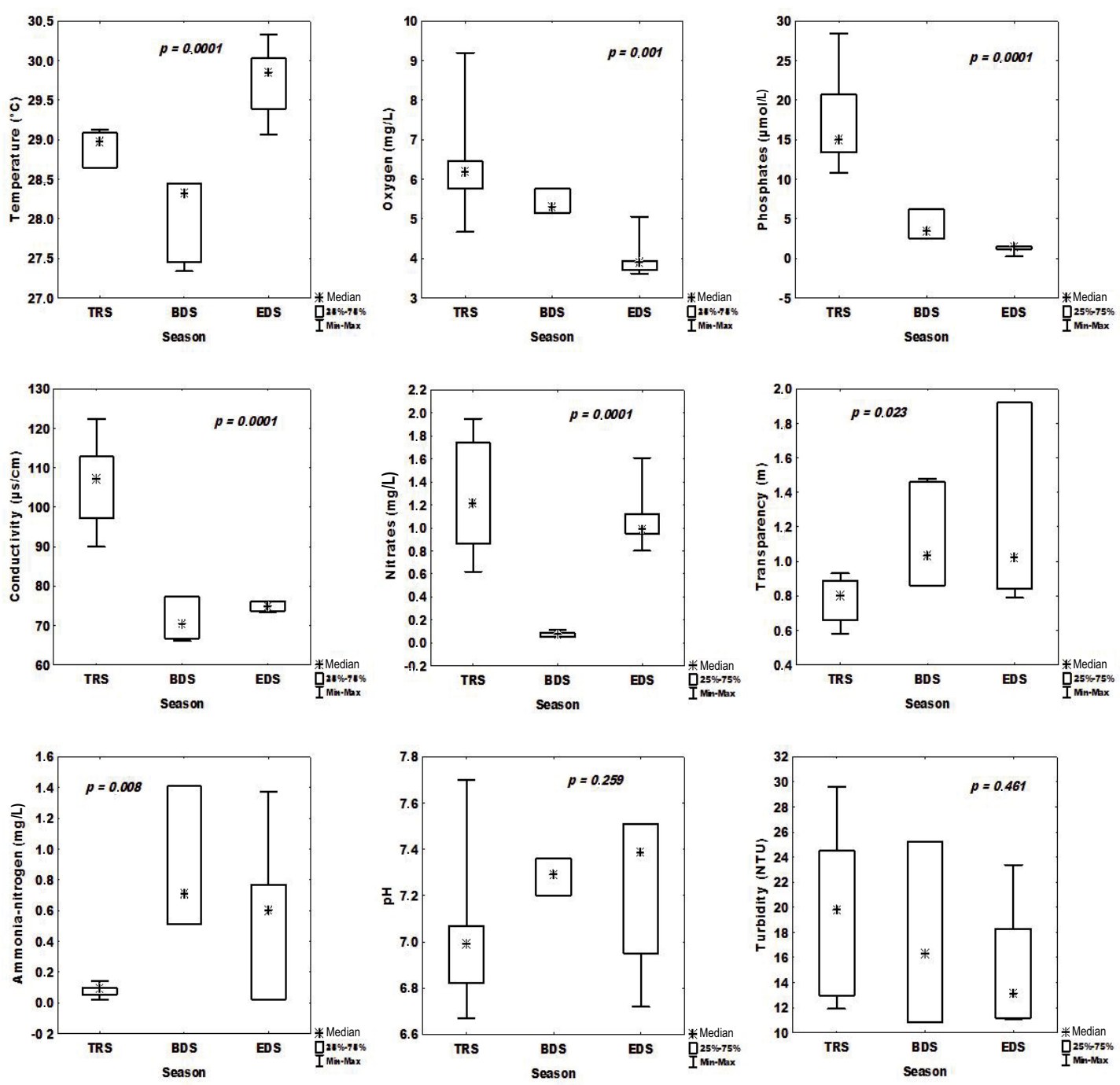

\section{Figure 2}

Seasonal variation in environmental variables in Lake Taabo; BDS = beginning of dry season, EDS = end of dry season, $M R S=$ major rainy season.

Figure 2

Variation saisonnière des variables environnementales dans le lac de Taabo; BDS = début de saison sèche, EDS = fin de saison sèche, TRS = pleine saison pluvieuse.

The number of taxa found exclusively in water hyacinth (10) was twice that found closely associated with littoral vegetation (5). There was equilibrium between the taxa which were considered low frequency (16) and sporadic (18). Only the family Chironomidae was most frequent for the whole period of study in all habitats, while eight taxa common in both microhabitats were also considered frequent. Three of them (Curculionidae, Dytiscidae and Hydrophilidae) were Coleoptera insects.

The average abundance of macroinvertebrates per $\mathrm{m}^{2}$ was $326 \mathrm{ind} \cdot \mathrm{m}^{-2}$ and $285 \mathrm{ind} \cdot \mathrm{m}^{-2}$ in habitats formed by water hyacinth and littoral vegetation, respectively (Table II). Five assemblages of macroinvertebrates were the most abundant: Veliidae (Heteroptera), Ceratopogonidae and Chironomidae (Diptera), Baetidae (Ephemeroptera) and Thiaridae (Gastropoda). However, the Chironomidae family exhibited higher density on both the littoral macrophyte habitat $(64 \%)$ and water hyacinth habitat $(47 \%)$ than that of the other communities. In addition to Chironomidae, Ceratopogonidae (12\%), Thiaridae (7\%) and Baetidae (7\%) were relatively 


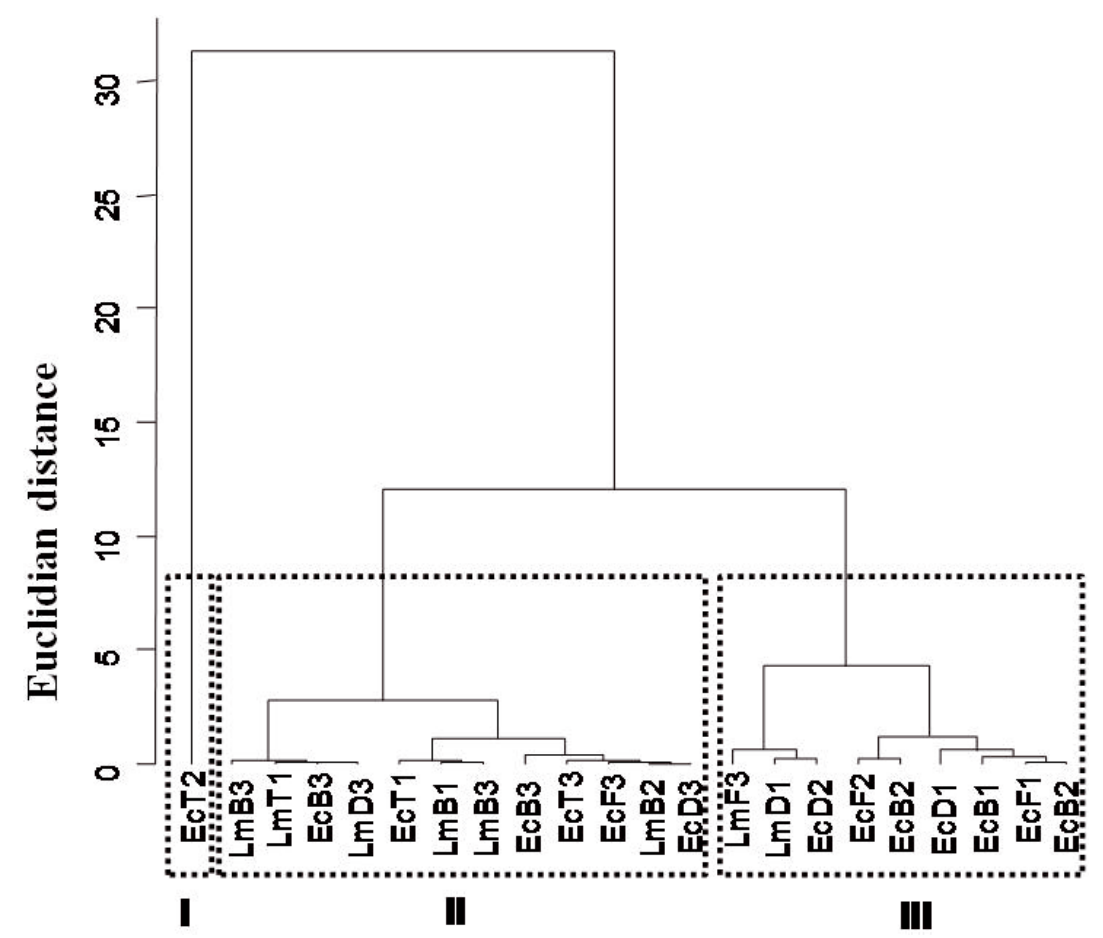

\section{Figure 3}

Hierarchical clustering based on similarities in aquatic macroinvertebrate patterns, of the different microhabitat types with a Ward linkage method and a Euclidean distance; Ec = Eichhornia crassipes, $L m$ = littoral macrophytes; 1 = beginning of dry season, $2=$ end of dry season and 3 = major rainy season; $F$ = fluvial zone, $T$ = transitional zone, $B=$ bay zone, $D=$ near the dyke.

\section{Figure 3}

Classification hiérarchique des différents types de microhabitats basée sur les similarités des assemblages des macroinvertébrés aquatiques, avec la méthode de Ward et la distance euclidienne comme distance d'assemblage $; \mathrm{Ec}=$ Eichhornia crassipes, $\mathrm{Lm}=$ végétation du littoral $; 1=$ début de saison sèche, 2 = fin de saison sèche et 3 = pleine saison pluvieuse; $F=$ zone fluviale, $T$ = zone de transition, $\mathrm{B}=$ zone de baie, $\mathrm{D}=$ près de la digue.

abundant on the $E$. crassipes habitat. Concerning the littoral macrophyte habitat, populations of Veliidae (8\%) and Thiaridae (7\%) followed the family of Chironomidae. Moreover, the density of Chironomidae and that of Thiaridae were similar between the two types of microhabitat. Samples were classified into three clusters by hierarchical cluster analysis (Figure 3 ). The first cluster was only composed of one sample of $E$. crassipes recorded in the transitional zone, at the end of the dry season. The second group includes samples of both E. crassipes and littoral macrophytes. This group was dominated by samples from the major rainy season (MRS) and mainly collected in the bay zones. The third cluster contained more samples of $E$. crassipes recorded in the dry season (BDS and EDS) at all the zones considered in this study (fluvial, dyke and bay zones), except samples recorded from the transitional zone. Thus, the cluster reveals that macroinvertebrate patterns of $E$. crassipes in the dry season differed from those of $E$. crassipes in the rainy season and those of littoral macrophytes recorded in the two seasons. The water hyacinth shares more organisms with littoral macrophytes in the rainy season than in the dry season.

The values of the indices (taxonomic richness $(R s)$, Shannon-Wiener index $\left(H^{\prime}\right)$ and Pielou evenness $(J)$ ) were not significantly different between the two habitat types according to the Mann-Whitney $U$ test $(P>0.05)$ (Figure 4), but relatively higher values of those indices were obtained with the water hyacinth habitat. However, significant seasonal variations in Shannon diversity $\left(H^{\prime}\right)$ levels were found (Figure 5 ) among the three sampling seasons (Kruskal-Wallis test, $H_{2,22}=7.36 ; P=0.025$ ). This difference was observed between the beginning of the dry 

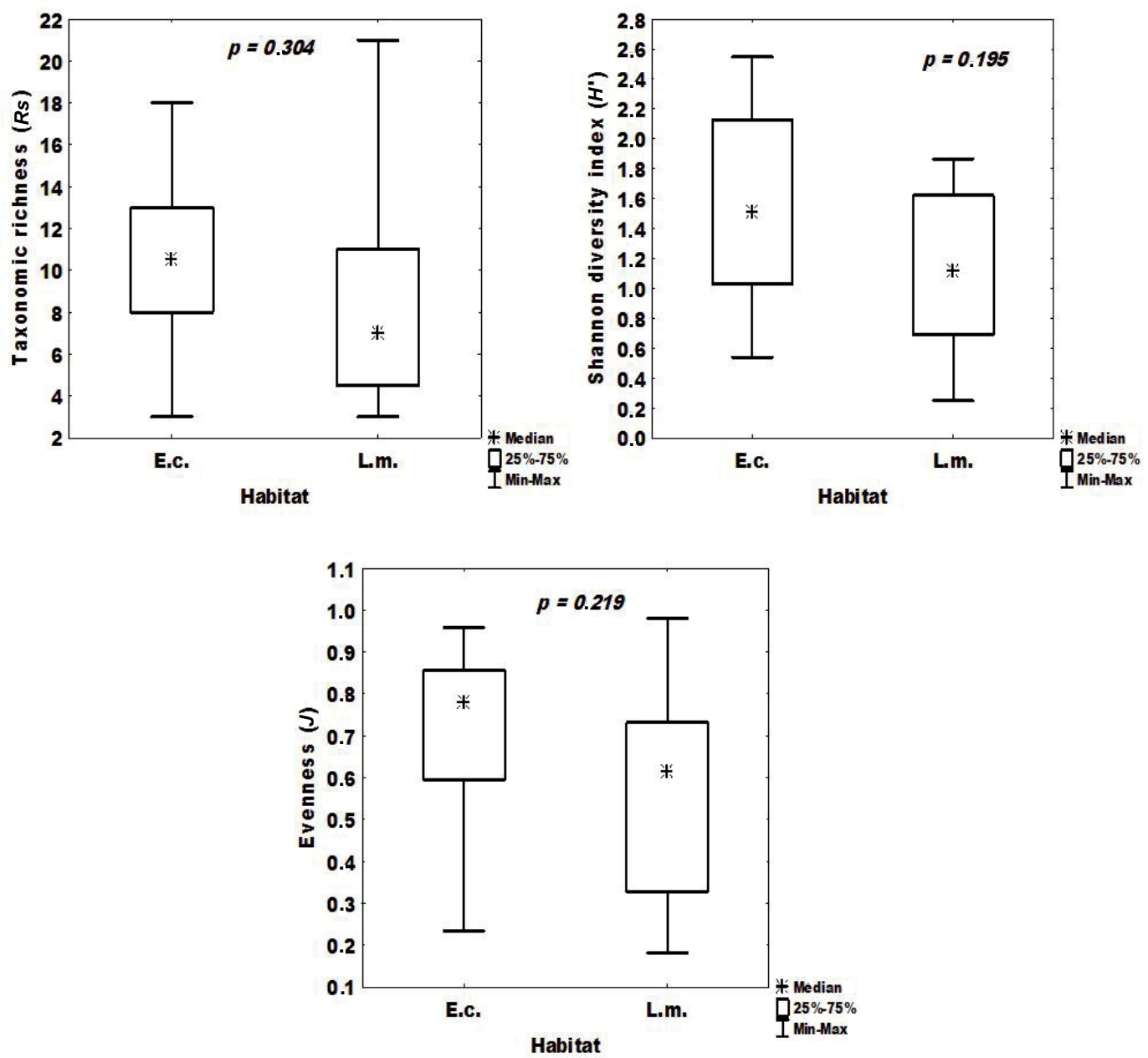

\section{Figure 4}

Macroinvetebrate taxon diversity measured for water hyacinth mats (E.c.) and littoral macrophyte microhabitat (L.m.).

\section{Figure 4}

Diversités des taxons de macroinvertébrés mesurées au niveau de la jacinthe d'eau (E.c.) et de la végétation du littoral (L.m.).

season (BDS) and the major rainy season (MRS), the difference outlined by a multiple comparison test $(P=0.02)$. Higher values of $H^{\prime}$ were registered in the BDS, while lower values were recorded in the MRS. The evenness index $(J)$ and the taxonomic richness $(R s)$ did not vary significantly from one season to another (ANOVA results of Kruskal-Wallis test, $P>0.05$ ). However, higher values of these two indices ( $J$ and $R s$ ) were observed in the BDS, while lower values were registered in the EDS.

\section{> RELATIVE INFLUENCE OF WATER PROPERTIES ON ASSOCIATED MACROINVERTEBRATE COMMUNITIES}

The results of the CCA showed that the first two CCA axes explained $43 \%$ of the relation species-environment (Table III) and $20.4 \%$ of the variation in species data (total inertia = 0.854).

From the CCA ordination diagram of macroinvertebrates in relation to water properties (Figure 6), one may deduce that the first principal component contrasts the transparency 

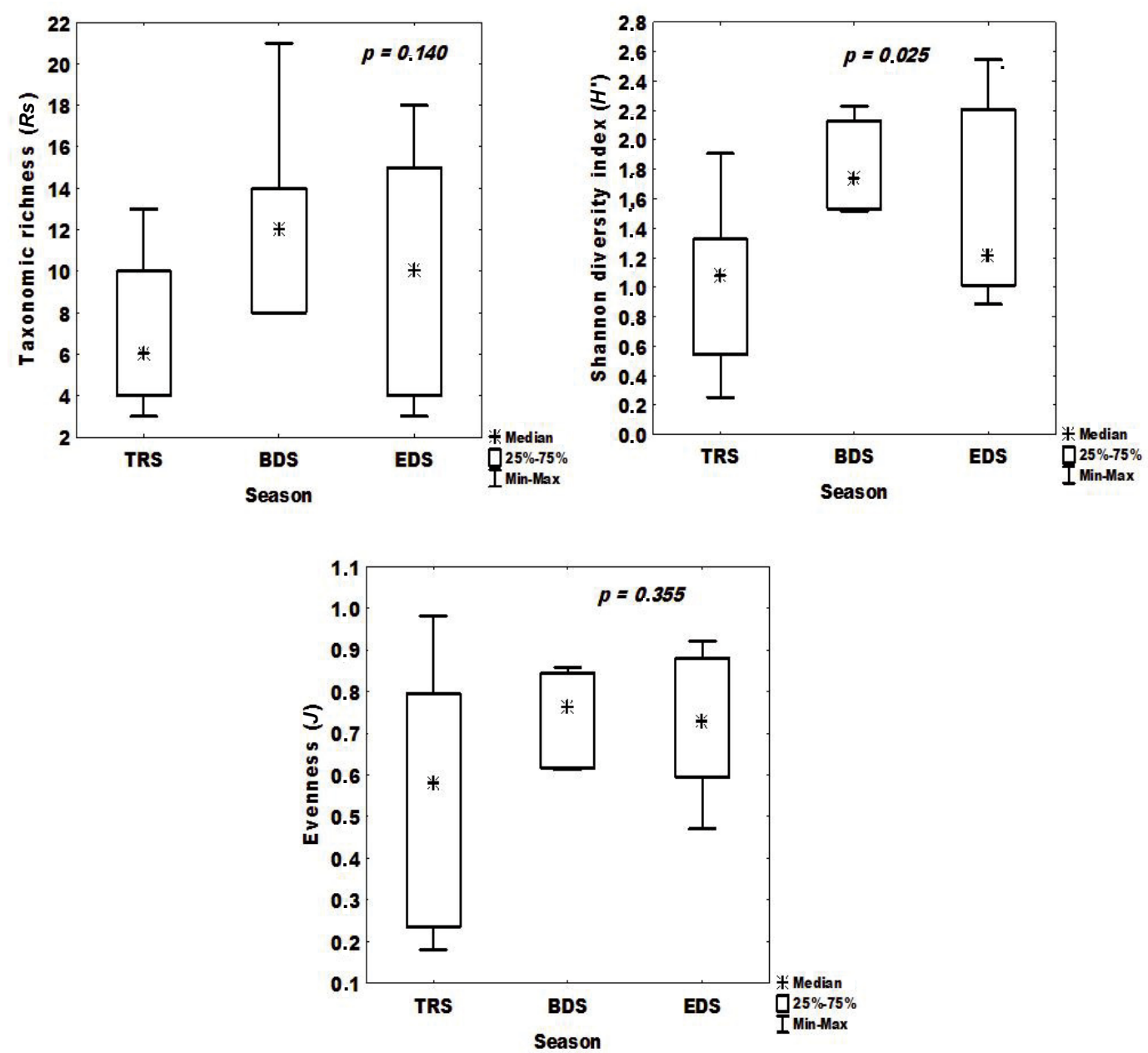

Figure 5

Macroinvetebrate taxon diversity measured for the different seasons of sampling; BDS = beginning of dry season, EDS = end of dry season, MRS = major rainy season.

\section{Figure 5}

Diversités des taxons de macroinvertébrés mesurées pendant les différentes saisons d'échantillonnage; $\mathrm{BDS}$ = début de saison sèche, EDS = fin de saison sèche, TRS = pleine saison pluvieuse.

and ammonia-nitrogen with all the other environmental variables. Those two parameters are most strongly and positively correlated with axis 1 . They were the most influential water variables that dictated the distribution of invertebrate groups such as Coleoptera (Curculionidae-Dytiscidae), Gastropoda (Lymnaeidae-Planorbidae-Thiaridae) and Odonata (Aeshnidae-Gomphidae-Macromiidae). The other variables, especially conductivity, phosphate, turbidity and dissolved oxygen, influenced the populations of Heteroptera (Pleidae-Belostomidae-Naucoridae), Ephemeroptera (Pothamanthidae-Baetidae) and Diptera (Chironomidae-Ceratopogonidae).

Concerning the CCA analysis of microhabitats created by aquatic macrophytes, the biplot showed that axis 1 was predominantly seasonal (Figure 7). Thus, the samples of macrophytes, essentially water hyacinth, collected in the dry season (BDS and EDS) were situated towards the right of axis 1, and the others, collected in the major rainy season (MRS), were situated towards the left of axis 1 . The dominant environmental variables positively correlated with axis 1 were transparency and ammonia-nitrogen (Figure 7). Other factors associated with axis 1 , but negatively, were conductivity, phosphates, dissolved oxygen and turbidity. Axis 2 was predominantly and negatively correlated with temperature and nitrate. 


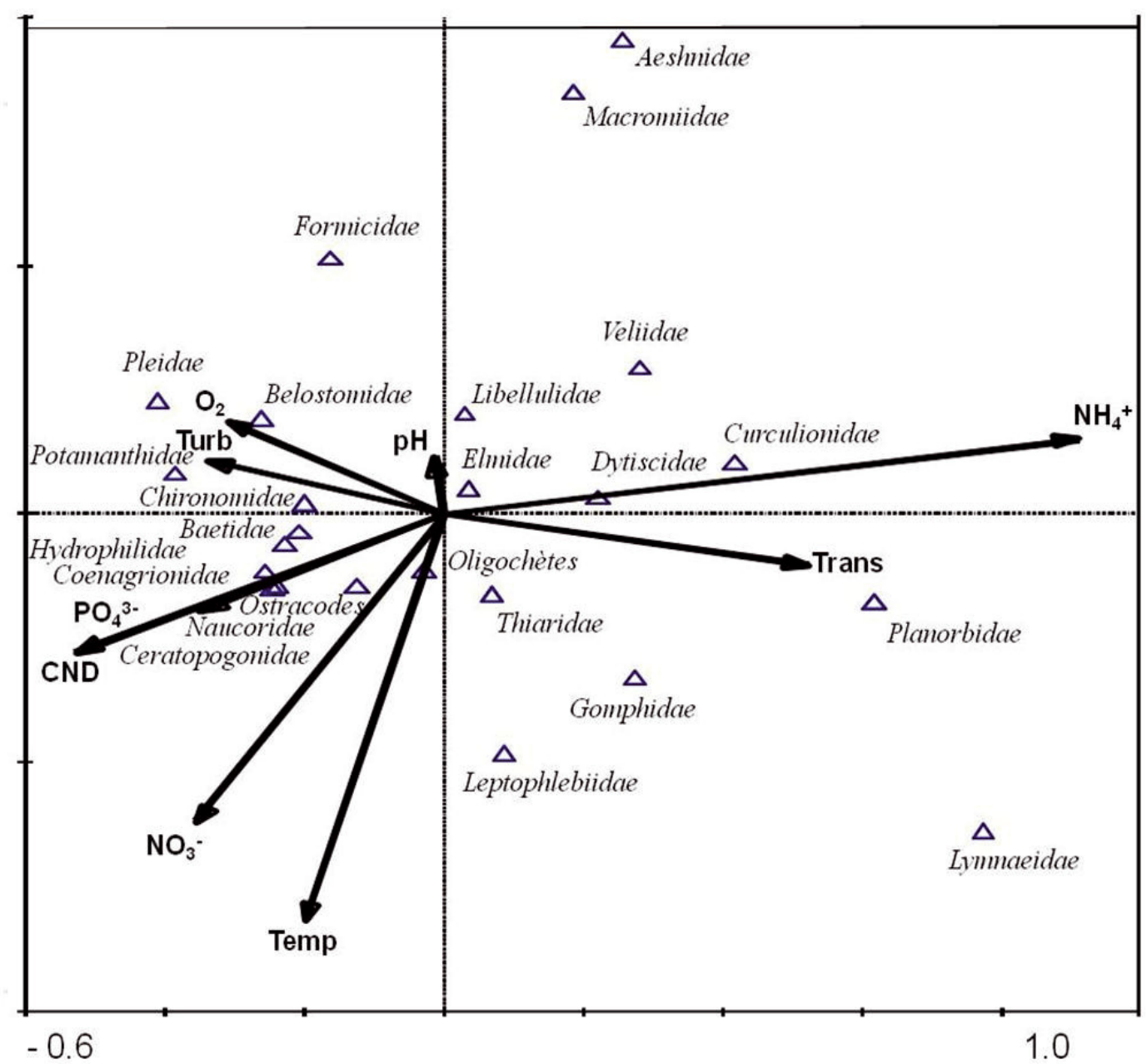

Figure 6

Canonical correspondence analysis (CCA) diagram of 24 macroinvertebrates in relation to nine water properties (arrows) measured $\left(\mathrm{pH}, \mathrm{O}_{2}=\right.$ dissolved oxygen, Turb = turbidity, $\mathrm{PO}_{4}^{3-}=$ phosphate, $\mathrm{CND}=$ electric conductivity, $\mathrm{NO}_{3}^{-}=$nitrate, Temp = temperature, Trans = transparency and $\mathrm{NH}_{4}^{+}=$ammoniumnitrogen).

\section{Figure 6}

Diagramme de l'analyse canonique des correspondances (CCA) de 24 macroinvertébrés en relation avec neuf paramètres de l'eau (flèche) mesurés $\left(\mathrm{pH}, \mathrm{O}_{2}=\right.$ oxygène dissous, Turb = turbidité, $\mathrm{PO}_{4}^{3-}=$ phosphate, $\mathrm{CND}=$ conductivité électrique, $\mathrm{NO}_{3}^{-}=$nitrate, Temp = température, Trans = transparence and $\mathrm{NH}_{4}^{+}=$ammonium).

Thus, from the two CCA diagrams (Figures 6 and 7), it seems that the microhabitat created by water hyacinth in the dry season was mostly characterised by the macroinvertebrate populations Coleoptera (Curculionidae-Dytiscidae), Gastropoda (Lymnaeidae-PlanorbidaeThiaridae) and Odonata (Aeshnidae-Gomphidae-Macromiidae). The communities of Heteroptera (Pleidae-Belostomidae-Naucoridae), Ephemeroptera (Pothamanthidae-Baetidae) and Diptera (Chironomidae-Ceratopogonidae) were found most commonly in both littoral macrophyte and $E$. crassipes habitats in the major rainy season (MRS).

\section{DISCUSSION}

This research work is the first study of aquatic macrophyte influence on the diversity of macroinvertebrates in Lake Taabo, a hydrosystem largely invaded by the floating plant 


\section{Table III}

Summary of the CCA results (a) for the first four ordination axes and (b) for the Monte-Carlo test.

Tableau III

Résumé des résultats de la CCA (a) pour les quatre premiers axes d'ordination et (b) pour le test de Monte-Carlo.

\begin{tabular}{|l|r|r|r|r|r|}
\hline Axes & 1 & 2 & 3 & 4 & \\
\hline Eigenvalues & 0.191 & 0.176 & 0.135 & 0.104 & \\
Species-environment correlations & 0.916 & 0.862 & 0.884 & 0.766 & \\
Cumulative percentage variance & & & & & \\
$\quad$ of species data & 10.6 & 20.4 & 27.9 & 33.7 & \\
$\quad$ of species-environment relation & 22.4 & 43.0 & 58.9 & 71.1 & \\
& & & & & \\
Sum of all eigenvalues (Total inertia) & & & & & 1.802 \\
Sum of all canonical eigenvalues & & & & & 0.854 \\
\hline
\end{tabular}

(a)

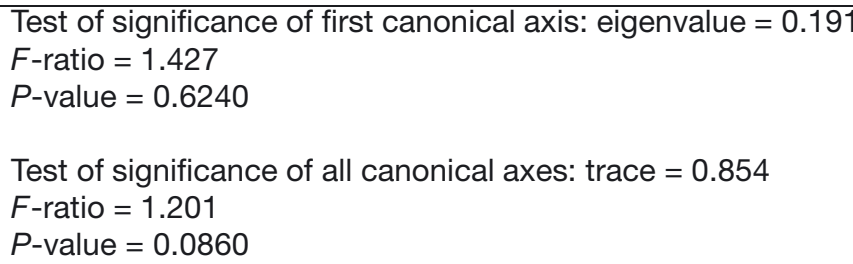

(b)

E. crassipes (26\% of the total surface according to Kouassi (2007)). This invasive plant was the only abundant plant recorded at all sampling sites in Lake Taabo. The others were recorded specially in the bay zone "Taabo cité". This may be due to the physical presence of water hyacinth which blocks sunlight and oxygen exchange, and hence prevents growth of emergent and submerged plants. The loss of submerged macrophytes is dramatic as they have an important structuring and regulating role in the ecosystem. Indeed, according to Jeppesen et al. (1997), they stabilise the sediment (reduction of turbidity) and compete for nutrients with phytoplankton. They also increase the sedimentation rate and provide shelter from planktivorous predators for zooplankton species.

As for environmental variables, they did not show significant variations among the sampling zones, except turbidity, which varied significantly between the fluvial zone and the site near the dyke, with higher values in the fluvial zone. This result could be explained by the flow velocity of water which is reduced near the dyke, increasing the accumulation of fine particles in the benthic zone. In terms of seasonal variations, only $\mathrm{pH}$ and turbidity were not significantly different from one season to another. All the other variables, except dissolved oxygen, varied significantly between the major rainy season (MRS) and the beginning of the dry season. Concerning dissolved oxygen values, significant variation was observed between the MRS and the end of the dry season, with higher values in the MRS. However, the values of this variable remained high (3.62 to $9.2 \mathrm{mg} \cdot \mathrm{L}^{-1}$ ). Those high concentrations of dissolved oxygen may be explained by the permanent presence of macrophytes in the lake which can modify the dissolved oxygen regimens as a consequence of photosynthetic activity (Carpenter and Lodge, 1986; Dudley et al., 1986).

In the present study, 43 taxa of macroinvertebrates, including 40 families, were recorded. This number of families could be considered high, when compared with previous studies carried out on water hyacinth and its associated macroinvertebrates. Indeed, Poi de Neiff and Carignan (1997), de Marco et al. (2001) and Brendonck et al. (2003) recorded, respectively, 40 families in two lakes of the Paraná River floodplain, 10 families in a eutrophic reservoir in tropical Brazil and 15 families in Lake Chivero. Among the families recorded from Lake Taabo, only three: Planorbidae (Gastropoda), Chironomidae (Diptera) and Libellulidae (Odonata) were recorded in each of the previous studies. However, 16, 10 and 9 families found 


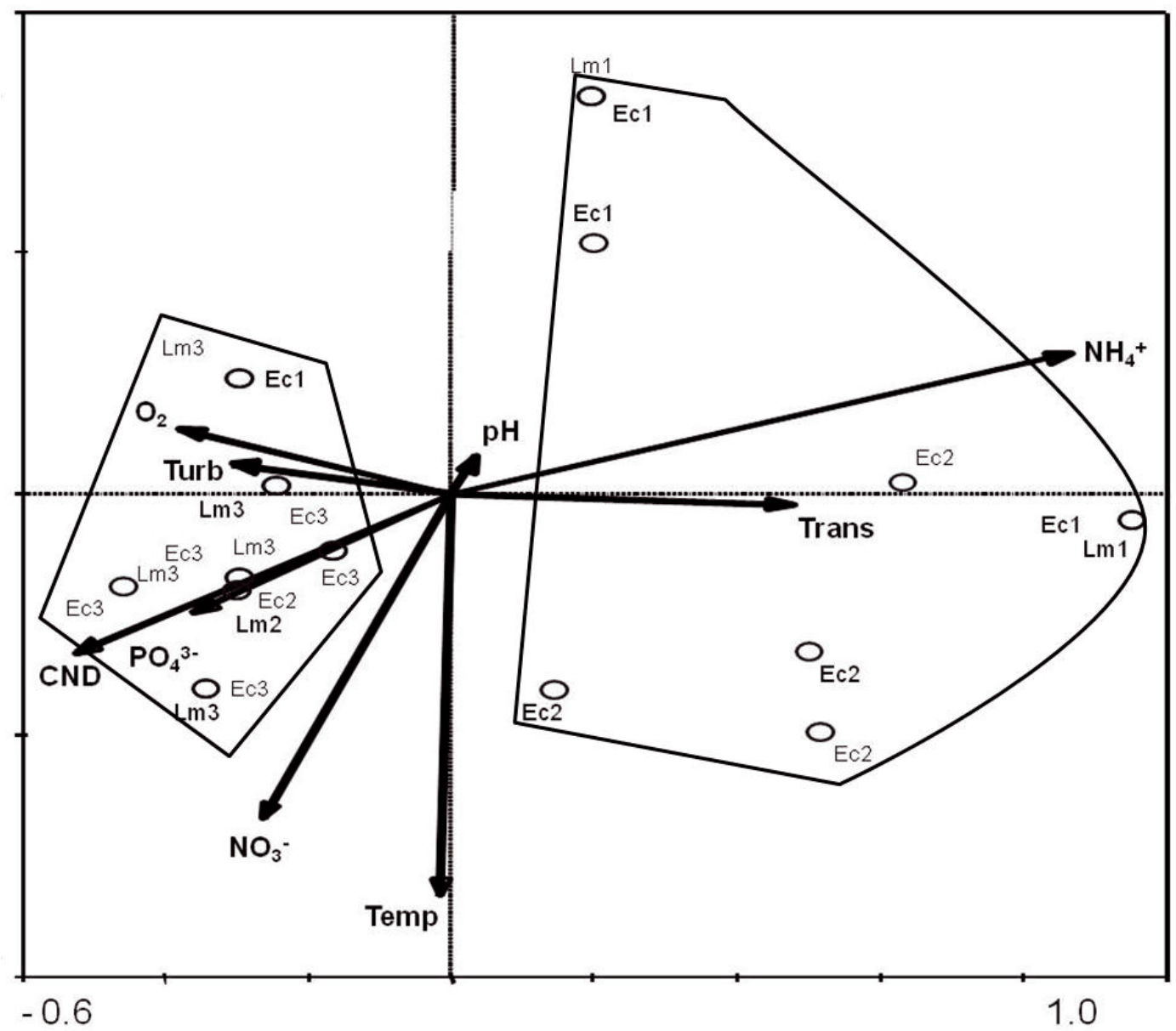

\section{Figure 7}

Canonical correspondence analysis (CCA) diagram of two types of microhabitats created by aquatic macrophytes ( $E c=$ Eichhornia crassipes, $L m=$ Littoral macrophytes) in relation to nine water properties (arrows) measured $\left(\mathrm{pH}, \mathrm{O}_{2}=\right.$ dissolved oxygen, Turb = turbidity, $\mathrm{PO}_{4}^{3-}=$ phosphate, $\mathrm{CND}=$ electric conductivity, $\mathrm{NO}_{3}^{-}=$nitrate, Temp = temperature, Trans = transparency and $\mathrm{NH}_{4}^{+}=$ammonium-nitrogen); 1 = beginning of dry season, 2 = end of dry season and 3 = major rainy season.

\section{Figure 7}

Diagramme de l'analyse canonique des correspondances (CCA) de deux types de microhabitats créés par les végétaux aquatiques ( $\mathrm{EC}=$ Eichhornia crassipes, $\mathrm{Lm}=$ végétation du littoral) en relation avec neuf paramètres de l'eau (flèche) mesurés $\left(\mathrm{pH}, \mathrm{O}_{2}=\right.$ oxygène dissous, Turb = turbidité, $\mathrm{PO}_{4}^{3-}=$ phosphate, $\mathrm{CND}=$ conductivité électrique, $\mathrm{NO}_{3}^{-}=$nitrate, Temp = température, Trans = transparence and $\mathrm{NH}_{4}^{+}=$ ammonium); 1 = début de saison sèche, 2 = fin de saison sèche et 3 = pleine saison pluvieuse.

in our study were also found, respectively, in those of Poi de Neiff and Carignan (1997), de Marco et al. (2001) and Brendonck et al. (2003). Also, Ali et al. (2007) found high species numbers (67 species) of invertebrates recorded in Lake Nasser amongst which 37 were exclusively epiphytic. This indicates that macrophytes provide excellent microhabitats that enhance the establishment and colonisation of many invertebrates.

Although some macroinvertebrate taxa were recorded in both microhabitats (water hyacinth mat and littoral macrophyte habitat), differences in taxon composition and abundance within the same taxonomic group (class or order) were observed. Similarly, Difonzo and Campbell (1988) found that relative abundance and composition of invertebrates varied depending on the type of microhabitat (e.g., plant species, benthic sediments or water column). In comparison with the water hyacinth microhabitat, littoral macrophytes had lower macroinvertebrate diversity. The significant differences in physical and chemical variables among sites 
with and without water hyacinths could, to some extent, cause these differences, as indicated by Rommens et al. (2003). According to these authors, the macrophyte habitat and morphology present in the lake mostly differs to a degree of structural complexity concerning the environment. Cheruvelil et al. (2002) indicated that the abundance of epiphytic invertebrates on aquatic macrophytes can be influenced by different plant architecture types. The water hyacinth floats and has a large radicular system available in the water column to be used as food and substrate by the macroinvertebrates. Kouamé et al. (2010) have observed that many macroinvertebrates associated with water hyacinth are herbivores or detritivores. The microenvironment created by the huge stand of the above macrophyte may have influenced other variables such as dissolved oxygen and may have been a determining factor in the high density and frequency of organisms found. On the other hand, littoral macrophytes are rooted plants which have a smaller area than $E$. crassipes. Their stand remained small and sparse throughout the whole study period, causing the taxa associated with them to be subject to higher abiotic variation. According to Cyr and Downing (1988), the differences in number of invertebrates in various macrophyte associations are considered as a result of the joint impact of a number of parameters and factors such as plant morphology, surface texture and nutrient content of plant tissues.

The high diversity (eight families) of snails in our study could be related to the lake's eutrophic state and an increase in calcium in the lake. Of these families, Thiaridae and Planorbidae were more frequently found on the two types of microhabitat and were the most abundant populations, especially the species Melanoïdes tuberculata Müller (Mesogastropoda: Thiaridae) and the genera Bulinus (Basommatophora: Planorbidae). Both species may have a competitive advantage over the other snails, due to rapid population increase and depletion of resources (Prentice, 1983; Dudgeon, 1986; Pointier and McCullough, 1989; Pointier et al., 1989). Although infections of the snails were not ascertained in our study, a mention needs to be made concerning bilharzia. Indeed, these two gastropods are vectors of this disease. Therefore, increased abundance of these two gastropods could pose a potential health hazard to the lakeside communities, particularly to fisherfolk and those who make regular contact with the lake water.

In most samplings, in view of the evenness values, the microhabitats studied showed a relative heterogeneity. The littoral macrophyte habitat showed a higher variation in evenness values. It also presented the lowest median value of evenness. Water hyacinth showed evenness values varying between 0.23 and 0.96 , with the highest median value. High levels of evenness indicate an environment with heterogeneous conditions regulated by a community which is rich in the number of species and the multiplicity of their mutual relationships (Schäfer, 1980). The values found in our study suggest that conditions were heterogeneous in some sampling sites and homogeneous in others, leading to a less rich community structure. Besides, taxonomic richness $(R s)$, the Shannon-Wiener index $\left(H^{\prime}\right)$ and Pielou evenness $(J)$ were not significantly different between water hyacinth and littoral macrophyte habitats, but relatively higher values of these indices were obtained with the water hyacinth habitat. This result suggests that the invasive plant's influence on macroinvertebrate diversity was not significant. Similar results were reported by Chilton (1990), who demonstrated that, whereas plant identity was an important factor influencing invertebrate abundance, the observed effects were not consistent across time. Besides, according to Thomaz et al. (2008), macrophyte identity plays a smaller role than macrophyte surface area or fractal complexity in explaining macroinvertebrate diversity and abundance. Also, Kovalenko et al. (2010) showed that the abundance of certain macrophytes could explain a small proportion of variability in macroinvertebrate communities, but the effect of this driver was not consistent among lakes or among the seasons. It may be supposed that Eichhornia crassipes is a permanent addition to Lake Taabo's macrophytes and in terms of aquatic macroinvertebrate communities it serves a similar function to the littoral plants.

The total density of macroinvertebrates found in the microhabitat created by $E$. crassipes was slightly higher than that found in the littoral macrophyte habitat. The groups which had the highest densities for both littoral vegetation and water hyacinth habitats were Chironomidae 
(Diptera), with $64 \%$ and $47 \%$, respectively, of all the organisms collected. Di Giovani et al. (1996) reported that the Chironomidae populations are almost always found to be numerically predominant, both in lotic and lentic environments, due to their tolerance of extreme conditions. Moreover, Merritt and Cummins (1996) indicated that the range of conditions under which chironomids are found is more extensive than that of any other group of aquatic insects, and their wide ecological amplitude is related to their very extensive array of morphological, physiological and behavioural adaptations.

It is evident that aquatic plants, especially Eichhornia crassipes plants, give a supplementary dimension to the studied hydrosystem ecology by adding an extra habitat for some macroinvertebrates. Thus, any monitoring programme of such invaded aquatic systems should take into account this created habitat. Indeed, a systematic destruction of the invasive introduced species could lead to a significant negative impact on the lacustrine ecosystem (e.g., effect on primary productivity and trophic structure).

\section{ACKNOWLEDGEMENTS}

This research was funded by the Committee on Scientific and Technological Cooperation of the Organisation of the Islamic Conference, Islamabad, Pakistan, and the International Foundation for Science, Stockholm, Sweden, through a grant to Dr Da Costa Kouassi Sebastino (Challenge programme FIS/CGIAR/COMSTECH).

The authors are grateful to Prof. Ake Assi of the Department of Botany at the University of Cocody, Abidjan, Côte d'Ivoire, who provided useful help and guidance for the identification of the macrophyte specimens. We also thank Dr Mexmin K. Konan, Charles K. Boussou and Gustave N. Aliko for their many constructive comments and critical review of the manuscript.

\section{REFERENCES}

Albertoni E.F., Prellvitz L.J. and Palma-Silva C., 2007. Macroinvertebrate fauna associated with Pistia stratiotes and Nymphoides indica in subtropical lakes (south Brazil). Braz. J. Biol., 67, 499-507.

Ali M.M., Mageed A.A. and Heikal M., 2007. Importance of aquatic macrophyte for invertebrate diversity in large subtropical reservoir. Limnologica, 37, 155-169.

American Public Health Association, 1989. Standard Methods for the Examination of Water and Wastewater, 17th edn., Washington, DC.

Barret S.C.H., 1989. Waterweed invasions. Sci. Am., 261, 90-97.

Batzer D.P., 1998. Trophic interactions among detritus, benthic midges and predatory fish in a freshwater marsh. Ecology, 79, 1688-1698.

Batzer D.P. and Wissinger S.A., 1996. Ecology of insect communities in nontidal wetlands. Annu. Rev. Entomol., 41, 75-100.

Brendonck L., Maes J., Rommens W., Dekeza N., Nhiwatiwa T., Barson M., Callebaut V., Phiri C., Moreau K., Gratwicke B., Stevens M., Alyn N., Holsters E., Ollevier F. and Marshall B., 2003. The impact of water hyacinth (Eichhornia crassipes) in a eutrophic subtropical impoundment (Lake Chivero, Zimbabwe). II. Species diversity. Arch. Hydrobiol., 158, 389-405.

Campbell J.M., Clark W.J. and Kosinski R., 1982. A technique for examining microspatial distribution of Cladocera associated with shallow water macrophytes. Hydrobiologia, 97, 225-232.

Carpenter S.R. and Lodge D.M., 1986. Effects of submersed macrophytes on ecosystem processes. Aquat. Bot., 26, 341-370.

Cheruvelil K.S., Soranno P.A. and Madsen J., 2001. Epiphytic macroinvertebrates along a gradient of Eurasian watermilfoil cover. J. Aquat. Plant Manage., 39, 67-72.

Cheruvelil K.S., Soranno P.A., Madsen J.D. and Roberson M.J., 2002. Plant architecture and epiphytic macroinvertebrate communities: the role of exotic dissected macrophyte. J. N. Am. Benthol. Soc., 21, 261-277.

Chilton II E.W., 1990. Macroinvertebrate communities associated with three aquatic macrophytes (Ceratophyllum demersum, Myriophyllum spicatum, and Vallisneria americana) in Lake Onalaska, Wisconsin. J. Freshwater Ecol., 5, 455-466. 
Crowder L.B. and Cooper W.E., 1982. Habitat structural complexity and the interaction between bluegills and their prey. Ecology, 63, 1802-1813.

Cyr H. and Downing J.A., 1988. Empirical relationships of phytomacrofaunal abundance to plant biomass and macrophyte bed characteristics. Can. J. Fish. Aquat. Sci., 45, 976-984.

de Marco P., Reis A.A., Barcelos M.K. and Barbosa L.M., 2001. Aquatic invertebrates associated with the water hyacinth (Eichhornia crassipes) in an eutrophic reservoir in tropical Brazil. Stud. Neotrop. Fauna Environ., 36, 73-80.

de Moor I.J., Day J.A. and de Moor F.C., 2003. Guide to the Freshwater Invertebrates of Southern Africa. Volume 7: Insecta I: Ephemeroptera, Odonata and Plecoptera, Rapport N TT 207/03 Water Research Commission, South Africa.

Déjoux C., Elouard J.M., Forge P. and Jestin J.M., 1981. Catalogue iconographique des insectes aquatiques de Côte d'Ivoire, Rapport ORSTOM 42.

Di Giovani M.V., Goretti E. and Tamanti V., 1996. Macrobenthos in Montedoglio Reservoir, central Italy. Hydrobiologia, 321, 17-28.

Diehl S., 1992. Fish predation and benthic community structure: The role of omnivory and habitat complexity. Ecology, 73, 1646-1661.

Difonzo C.D. and Campbell J.M., 1988. Spatial partitioning of microhabitats in littoral cladoceran communities. J. Freshwater Ecol., 4, 303-313.

Diomandé D., Gourène G., Sankaré Y. and Zabi S.G., 2000. Synopsis de la classification des larves et des nymphes de Diptères Chironomidae des écosystèmes dulçaquicoles de l'Afrique de l'Ouest. Clés de détermination des sous-familles, des tribus et des genres. CRO, Abidjan. Arch. Scient., 17, 1-31.

Downing J.A. and Cyr H., 1985. Quantitative estimation of epiphytic invertebrate populations. Can. J. Fish. Aquat. Sci. , 42, 1570-1579.

Dudgeon D., 1986. The life cycle, populations dynamics and productivity of Melanoides tuberculata (Muller, 1774) (Gastropoda: Prosobranchia: Thiaridae) in Hong Kong. J. Zool., 208, 37-53.

Dudley T.L., Cooper S.D. and Hemphill N., 1986. Effects of macroalgae on a stream invertebrate community. J. N. Am. Benthol. Soc., 5, 93-106.

Durand J.R. and Lévêque C., 1980. Faune et flore aquatiques de l'Afrique Sahalo-soudanienne, 1, ORSTOM, Paris.

Durand J.R. and Lévêque C., 1981. Faune et flore aquatiques de l'Afrique Sahalo-soudanienne, 2, ORSTOM, Paris.

Havens K.E., 1991. Summer zooplankton dynamics in the limnetic and littoral zones of a humic acide lake. Hydrobiologia, 215, 21-29.

Jeppesen E., Jensen J.P., Sondergaard M., Lauridsen T., Pedersen L.J. and Jensen L., 1997. Top-down control in freshwater lakes: the role of nutrient state, submerged macrophytes and water depth. Hydrobiologia, 342, 151-164.

Kouamé K.M., Diétoa Y.M., Da Costa K.S., Edia O.E., Ouattara A. and Gourène G., 2010. Aquatic macroinvertebrate assemblages associated with root masses of water hyacinths, Eichhornia crassipes (Mart.) Solms-Laubach, 1883 (Commelinales: Pontederiaceae) in Taabo Lake, Ivory Coast. J. Nat. Hist., 44, 257-278.

Kouassi K.L., 2007. Hydrologie, transport solide et modélisation de la sédimentation dans les lacs des barrages hydroélectriques de Côte d'Ivoire : Cas du lac de Taabo. Ph.D. Thesis, University of Abobo-Adjamé, Abidjan, Côte d'Ivoire.

Kovalenko K.E., Dibble E.D. and Slade J.G., 2010. Community effects of invasive macrophyte control: role of invasive plant abundance and habitat complexity. J. Appl. Ecol. , 47, 318-328.

Lauridsen T.L. and Buenk I., 1996. Diel changes in the horizontal distribution of zooplankton in the littoral zone of two shallow eutrophic lakes. Arch. Hydrobiol., 137, 161-176.

Lodge D.M., 1991. Herbivory on freshwater macrophytes. Aquat. Bot., 41, 195-224.

Luken J.O. and Thieret J.W., 1997. Assessment and management of plant invasions, Springer, New York. Magurran A.E., 1988. Ecological Diversity and its Measurement, Croom Helm, Ryde.

Merritt R.W. and Cummins K.W., 1996. Aquatic insects of the North America, Dubuque: Kendall/Hunt Publishing Company.

Munro J.L., 1966. A limnological survey of lake Mcllwaine, Rhodesia. Hydrobiologia, 28, 281-308.

Ogutu-Ohwayo R., Hecky R.E., Cohen A.S. and Kaufman L., 1997. Human impacts on the African Great Lakes. Environ. Biol. Fish., 50, 117-131. 
Olson E.J., Engstrom E.S., Doeringsfeld M.R. and Bellig D.R., 1994. Abundance and distribution of macroinvertebrates in relation to macrophyte communities in a prairie marsh, Swan Lake, Minnesota. J. Freshwater Ecol., 1014, 325-335.

Poi de Neiff R. and Carignan A., 1997. Macroinvertebrates on Eichhornia crassipes roots in two lakes of the Paraná River floodplain. Hydrobiologia, 345, 185-196.

Pointier J.P. and McCullough F., 1989. Biological control of the snail hosts of Schistosoma mansoni in the Caribean area using Thiara spp. Acta Trop., 46, 147-155.

Pointier J.P., Guyard A. and Mosser A., 1989. Biological control of Biomphalaria glabrata and $B$. straminea by the competitor snail Thiara tuberculata in a transmission site of schistosomiasis in Martinique, French West Indies. Ann. Trop. Med. Parasitol., 83, 263-269.

Prentice M.A., 1983. Displacement of Bomphalaria glabrata by the snail Thiara granifera in field habitats in St. Lucia, West Indies. Ann. Trop. Med. Parasitol., 77, 51-59.

Rennie M.D. and Jackson L.J., 2005. The influence of habitat complexity on littoral invertebrate distributions: Patterns differ in shallow prairie lakes with and without fish. Can. J. Fish. Aquat. Sci., 62, 2088-2099.

Rommens W., Maes J., Dekeza N., Inghelbrecht P., Nhiwatiwa T., Holsters E., Ollevier F., Marshall B. and Brendonck L., 2003. The impact of water hyacinth (Eichhornia crassipes) in a eutrophic subtropical impoundment (Lake Chivero, Zimbabwe). I. Water quality. Arch. Hydrobiol., 158, 373-388.

Sakho M.A., 1991. Indice de l'instabilité des ressources en eau sur la gestion d'un système d'eau aménagé. Exemple du bassin versant du Sassandra en Côte d'Ivoire. Ph.D. Thesis, University of Montpellier II, France.

Savage A.A. and Beaumont D.L., 1997. A comparison of the benthic macroinvetebrate communities of a lowland lake, Oak Mere, in 1980 and 1994. Arch. Hydrobiol., 139, 197-206.

Schäfer A., 1980. Critérios e Métodos para a avaliação das águas superficiais - Análise de diversidade de Biocenoses. Porto Alegre: Ed. Da Universidade Federal do Rio Grande do sul, NIDECO Série Taim, 3, 24-41.

Taniguchi H., Nakano S. and Tokeshi M., 2003. Influences of habitat complexity on the diversity and abundance of epiphytic invertebrates on plants. Freshwater Biol., 48, 718-728.

ter Braak C.J.F. and Smilauer P., 2002. CANOCO reference manual and CanoDraw for Windows user's guide: Software for canonical community ordination (Version 4.5), Microcomputer Power, Ithaca, New York

Thomaz S.M., Dibble E.D., Evangelista L.R., Higuti J. and Bini L.M., 2008. Influence of aquatic macrophyte habitat complexity on invertebrate abundance and richness in tropical lagoons. Freshwater Biology, 53, 358-367.

Timms R.M. and Moss B., 1984. Prevention of growth of potentially dense phytoplankton populations by zooplankton grazing in the presence of zooplanktivorous fish in shallow wetland ecosystem. Limnol. Oceanogr., 29, 472-486.

Toft J.D., Simenstad C.A., Cordell J.R. and Grimaldo L.F., 2003. The Effects of Introduced Water Hyacinth on Habitat Structure, Invertebrate Assemblages, and Fish Diets. Estuaries, 26, 746-758.

van den Berg M.S., Coops H., Noordhuis R., van Schie J. and Simons J., 1997. Macroinvertebrate communities in relation to submerged vegetation in two Chara-dominated lakes. Hydrobiologia, 342/343, 143-150.

Vijverberg J. and Boersma M., 1997. Long-term dynamics of small-bodied and large-bodied cladocerans during the eutrophication of a shallow reservoir, with special attention for Chydorus sphaericus. Hydrobiologia, 360, 233-242.

Williams D.D., 1980. Some relationships between stream benthos and substrate heterogeneity. Limnol. Oceanogr., 25, 161-172.

Wilzbach M.A., 1985. Relative roles of food abundance and cover in determining the habitat distribution of streamdwelling cutthroat trout (Salmo clarki). Can. J. Fish. Aquat. Sci., 42, 1668-1672.

Wilzbach M.A., Cummins K.W. and Hall J.D., 1986. Influence of habitat manipulations on interactions between cutthroat trout and invertebrate drift. Ecology, 67, 898-911.

Zimmer K.D., Hanson A.M. and Butler M.G., 2000. Factors influencing invertebrate communities in prairie wetlands: A multivariate approach. Can. J. Fish. Aquat. Sci., 57, 76-85. 